Southern Methodist University

SMU Scholar

Sociology Research

Sociology

Summer 7-31-2007

\title{
Systems of Distribution and a Sense of Equity: A Multilevel Analysis of Meritocratic Attitudes in Post-industrial Societies
}

\author{
Sheri L. Kunovich \\ Southern Methodist University, kunovich@smu.edu \\ Kazimierz M. Slomczynski \\ Ohio State University - Main Campus, slomczynski.1@sociology.osu.edu
}

Follow this and additional works at: https://scholar.smu.edu/hum_sci_sociology_research

Part of the Inequality and Stratification Commons, Other Sociology Commons, Personality and Social Contexts Commons, Politics and Social Change Commons, Social Psychology and Interaction Commons, Sociology of Culture Commons, and the Theory, Knowledge and Science Commons

\section{Recommended Citation}

Kunovich, Sheri L. and Slomczynski, Kazimierz M., "Systems of Distribution and a Sense of Equity: A Multilevel Analysis of Meritocratic Attitudes in Post-industrial Societies" (2007). Sociology Research. 4. https://scholar.smu.edu/hum_sci_sociology_research/4

This document is brought to you for free and open access by the Sociology at SMU Scholar. It has been accepted for inclusion in Sociology Research by an authorized administrator of SMU Scholar. For more information, please visit http://digitalrepository.smu.edu. 
Southern Methodist University

SMU Digital Repository

Sociology Research

7-31-2007

Systems of Distribution and a Sense of Equity: A Multilevel Analysis of Meritocratic Attitudes in Post-industrial Societies

Sheri L. Kunovich

Kazimierz M. Slomczynski

This document is brought to you for free and open access by the Sociology at SMU Digital Repository. It has been accepted for inclusion in Sociology Research by an authorized administrator of SMU Digital Repository. For more information, please contact robertw@mail.smu.edu, cholloway@mail.smu.edu. 


\title{
Systems of Distribution and a Sense of Equity: A Multilevel Analysis of Meritocratic Attitudes in Post-industrial Societies
}

\author{
Sheri Kunovich and Kazimierz M. Slomczynski
}

Meritocratic attitudes are defined as general beliefs that education and its correlates should determine personal economic outcomes. Using the International Social Survey Project (ISSP): Social Inequality Module (1992), we examine both individual-level and country-level determinants of pro-meritocratic attitudes. According to self-interest and rational-action theories, individuals with high educational attainment and high personal income are expected to have strong meritocratic beliefs because meritocracy is in their best interest-they would gain under such a system. At the same time, both modernization and post-industrial theories imply that persons living in countries with a high degree of societal meritocracy hold stronger meritocratic beliefs than persons living in countries with low degree of societal meritocracy. Results of the Hierarchical Linear Modeling (HLM) analysis on a data set including 7,972 persons from 14 countries indicate that the impact of individuals' education and income on meritocratic attitudes occurred as theoretically predicted. We also demonstrate that the relationship between the degree of societal meritocracy and the degree of support for such a system is statistically significant even if national wealth and educational stock (as well as individual-level variables) are controlled. In addition, we discovered that at the beginning of the 1990 s a post-communist regime had a negative effect on support for meritocracy.

\section{Introduction}

Past research has identified various individual-level determinants of attitudes towards social inequality and the conditions under which injustice is perceived (Jasso and Rossi, 1977; Alves and Rossi, 1978; Jasso, 1978; Robinson and Bell, 1978; Jasso, 1980; Wesolowski, 1981; Krauze and Slomczynski, 1985; Shepelak and Alwin, 1986; Shepelak, 1989; Ritzman and Tomaskovic-Devey, 1992). Moreover, comparative researchers have identified a cross-national pattern with respect to how individuals justify inequality (Mateju and Rehakova, 1992; Mateju and Tucek, 1992; Kelley and Evans, 1993; Kluegel et al., 1995), including meritocratic beliefs (Shepelak, 1989; Mateju and Rehakova, 1992; Mateju and Tucek, 1992; Locklear, 1998; Slomczynski and Wesolowski, 2001). However, none of the published studies have examined meritocratic attitudes in the context of both individual-level and country-level determinants. Do individuals with high educational attainment and high personal income have strong meritocratic beliefs 
independent of the degree of actual meritocracy achieved in the countries in which they live? Does the degree of societal meritocracy, defined on the country-level, affect people's attitude toward meritocracy independent of their education and income? Ours is the first study to examine these theoretically relevant issues by using the Hierarchical Linear Modeling (HLM) framework.

In this article, we introduce new scales of meritocratic attitudes that can be used cross-nationally, and examine conditions under which people legitimate inequality on the basis of merit. We emphasize the importance of contextual variables, in particular the degree of actual meritocracy, for the formation of attitudes regarding just (equitable) distribution. Using the International Social Survey Project (ISSP): Social Inequality Module that includes appropriate data on 7,972 individuals from 14 countries for 1992, we test specific hypotheses about the impact of both individual-level variables (education and income) and country-level variables (societal meritocracy). The article begins with a short discussion of theoretical background and formulation of hypotheses. Then, we proceed to our main contribution of methodological and substantive matter. In particular, we present a multilevel analysis of a complex set of independent variables and demonstrate their net effects on promeritocratic stances in an interpretable manner. At the end of the article, we discuss some implications of the individual- and country-level effects in the context of radical social change in the post-communist societies.

\section{Theoretical Background and Main Hypotheses}

\section{Meritocracy: Actual and Desired}

The concept of meritocracy refers to a large-scale social system in which a positive relationship exists between 'merit' and such commonly desired resources as income, power, and prestige. In various theoretical contexts, merit is measured in several ways including cognitive skills or educational attainment and desired resources (rewards) are inferred from occupation or earnings. In this article, we refer to an 'educationincome' meritocracy since it is well-grounded in both modernization and post-industrial theory.

Modernization and post-industrial theories postulate that educational attainment will increasingly become the mechanism through which people are selected into jobs. In accordance with this theory, Daniel Bell $(1973,1996)$ argues that theoretical knowledge forms the 'axial principle' around which modern societies are structured. In post-industrial societies, firms no longer compete over material resources; rather they compete for new technological and organizational solutions that stem from innovation. Innovation in post-industrial societies is induced to a great degree by the tertiary educational experience. As a result of the inherent rationality of a post-industrial society, firms seek the most highly educated labourer they can attract given the rewards at their disposal, earnings and possibly benefits. Therefore, a post-industrial society is in its logic a meritocracy where the highly educated are the most rewarded (Halsey, 1967; Dahrendorf, 1968; Bell, 1973; Husen, 1974; Krauze and Slomczynski, 1985).

Meritocracy is considered not only a rational justification for inequality but also a just system of distribution. The equity principle, understood as a desirable rule of distribution (Cook, 1975; Deutsch, 1975; Bierhoff et al., 1986), postulates that the value of inputs should equal, in its standardized form, the value of outputs. When inputs are defined as educational achievement and outputs are defined as financial resources, the balancing of the two results in a meritocratic allocation. Thus, meritocratic allocation endorses a specific form of equity (Bénabou, 2000).

Societies differ in the degree to which meritocratic allocation is achieved (Krauze and Slomczynski, 1985; Jonsson, 1989; Saunders, 1995; for a critical assessment of the concept of meritocracy, see Goldthorpe 1996). Do these differences affect the extent to which people support meritocracy? Is there any covariation between the degree of societal meritocracy and the strength of meritocratic attitudes? To answer these questions, we need to discuss meritocracy in its subjective sense- that is as a popular belief according to which the balance between merit and rewards should be maintained.

To assess who favours a balance between education and income, people should be directly asked about various aspects of personal merit (such as education and training, and responsibility) producing economic gain (earnings in particular). However, other indirect indicators may be used as well. Invoking the family situation as a criterion for deciding pay on the job is an example of an anti-meritocratic stance. Similarly, those who support governmental policies that aim at assuring full employment are more anti-meritocratic than those who oppose such policies. As in all survey research seeking to measure attitudes towards distributive justice, respondents must be confronted with 


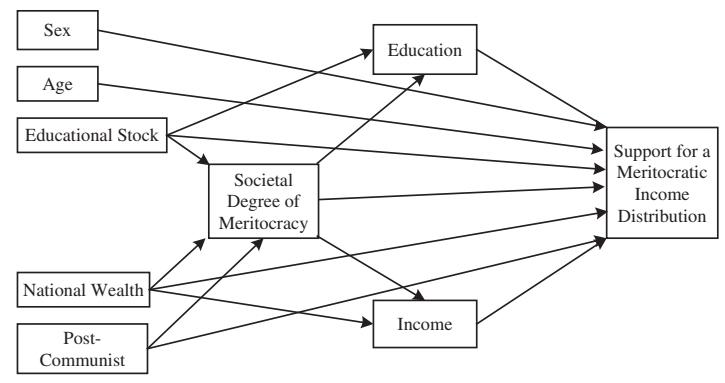

Figure 1 Theoretical model

questions containing a normative component: what should be rather than what is.

\section{A Model and Hypotheses}

Figure 1 presents the relationship between both individual and contextual independent variables and how they affect attitudes towards the distribution of income on the basis of merit. The causal model identifies the direct effects of education, income, societal degree of meritocracy, educational stock, national wealth, and a type of political regime. It also takes into account individual control variables—sex and age. We will explain the meaning and theoretical importance of these variables.

Individual determinants of economic justice are usually interpretable in terms of expected gains and losses (Homans, 1967; Swift and Marshall, 1997). Within the framework of both self-interest theory and rational action theories, one would expect that persons with high levels of education endorse a system where rewards are determined by merit, in particular education and its correlates, because they will gain from this system. Persons with lower education will oppose pro-meritocratic policies in determining income because under such policies they are likely to lose.

In agreement with this line of theorizing, past research has shown that persons of higher levels of income tend to support inequality more than persons with lower levels of income (Robinson and Bell, 1978; Ritzman and Tomaskovic-Devey, 1992). Those who are currently benefiting from the system are more likely to prefer a system in which income inequalities are not restricted and do not depend on needs. Those with low incomes would be opposed to merit determining pay because merit-based criteria usually lead to greater inequality and ignore differing individual needs.
In a general form, our first hypothesis refers to the crucial individual level variables and states that education and income have a positive impact on pro-meritocratic attitudes. In particular, we expect that (i) within each country there is a positive and statistically significant correlation between education and income and support for merit-based pay. We also expect that (ii) within each country after controlling for age and sex both independent variables_education and income-have a positive and statistically significant net effect on pro-meritocratic attitudes. Finally, we expect that (iii) education and income explain a significant proportion of variation in pro-meritocratic attitudes across countries.

The second type of hypotheses pertains to countrylevel variables: the degree of actual meritocracy and its main correlates, including national wealth and educational stock. We expect the most important contextual predictor of meritocratic attitudes to be the degree to which there is an association between merit and reward at the societal level. The degree of actual meritocracy affects attitudes toward such a system because individuals realize that earned economic rewards are determined by merit. In particular, individuals view merit as a legitimate basis upon which to establish pay, as a result of living in a post-industrial society where knowledge is necessary for economic advancement.

The actual degree of meritocracy is influenced, with some time-lag, by the educational and financial resources of a society. However, both educational stock and national wealth can exercise an independent effect on beliefs about meritocracy. We expect that the greater the proportion of highly educated individuals in a society, the greater the tendency that merit is viewed as a legitimate way to reward individuals. National wealth, in addition to affecting the degree of meritocracy and the educational stock, also influences individual attitudes towards meritocracy-as suggested by modernization theory. Wealthier societies are characterized by inequality that, if based on achievement, is popularly perceived as legitimate (So, 1990). Therefore, we can expect that persons living in wealthier societies will believe that merit determines economic success and the merit should determine future pay.

Although it is important to control for the effects of the experience with a welfare state on attitudes (Kluegel and Miyano, 1995; Gelissen, 2000; Andre $\beta$ and Heien, 2001; Arts and Gelissen, 2001; Svallfors, 2003), we focus on the fact that living in any type of traditional capitalist society pre-disposes a person to hold meritocratic attitudes. ${ }^{1}$ In contrast, living in 
a society where equal benefits are given to all is conducive to a belief that merit plays less of a natural role in determining outcomes. Thus, people living in post-communist societies should oppose meritocracy given their experiences under a socialist economic system. To examine this effect, one should take into account the period of the early phase of the postcommunist transformation - the phase of radical social change. Summarizing, our country-level hypotheses predicts that (i) the degree of meritocracy, educational stock, and national wealth has a positive effect on support for meritocracy; in contrast, (ii) a postcommunist regime has a negative effect on support for meritocracy.

In the case of country-level characteristics included in our model, the direction of causality needs some explanation, particularly pertaining to the impact of societal meritocracy on pro-meritocratic attitudes. Is the reverse causal relationship plausible? Are countries with people having stronger pro-meritocratic attitudes likely to establish a meritocratic distribution of income? Our answer to this type of question is negative, since in the theoretical framework adapted in this article meritocratic rules operating on the labour market are introduced due to economic factors. Those who set up these rules are motivated by expected productivity and profits-not by the public opinion. In other words, the public opinion can adjust to these rules but it is not a force that shapes them. Analogically, we extend this reasoning about the causal priority of country-level variables-educational stock, national wealth, and post-communist regime-over individual level variables. We time-order our variables included in model in accordance with this reasoning, thus avoiding confusion regarding what causes what.

We should also note that theoretically educational and income inequality could also influence societal meritocracy and pro-meritocratic attitudes. However, since the degree of meritocracy analytically implies a certain degree of inequality, we have good reason to omit the latter. By definition, meritocracy captures inequality to a considerable extent (Bénabou, 2000).

\section{Data and Measurement}

International Social Survey Project (ISSP): Social Inequality Module, administered in 1992, is the result of the collaborative efforts of researchers in Europe, North America, Australia and New Zealand. We restricted our analysis to countries listed in the Appendix. Their population varies from 3.4 million in New Zealand to 252.2 million in the United States.
Although all of these countries are industrialized, they differ greatly with respect to levels of economic development and investment in education. Moreover, some have been classified as traditional or welfare capitalist systems while others belong to the postcommunist block. We focus on the core of the labour force defined as people 21-65 years old classified as full-time employees, constituting from 31.1 to 51.7 per cent of the original national samples. ${ }^{2}$ In the Appendix, we note specific features of the samples, data collection, and data quality. Although our analyses have not revealed that these methodological cross-national differences have any effect on substantive results presented in this article, the reader oriented toward case studies should be aware of them since they may be pertinent for interpretation of national-specific findings.

\section{Measurement of Meritocratic Attitudes}

We use six questionnaire items to construct the index of support for a meritocratic distribution of income. The first five items refer to the block of questions in which the respondent was asked to state how important the following factors should be in determining pay (1) the number of years spent in education and training, (2) the amount of responsibility that goes with the job, (3) how well the person does the job, (4) what is needed to support a family, and (5) whether the person has children to support. In all of these questions, a five-point scale ranging from essential to not important at all was used. Applying face-validity criterion, we assume that for items (1), (2), and (3) the response essential and for items (4) and (5) the response not important (either not important at all or not very important) indicates a pro-meritocratic stance. In addition, we assume that agreeing with the statement (6) the government should provide jobs for everyone who wants one indicates an anti-meritocratic stance, since the policy implied by this statement disregards any merit-based consideration in allocating people to jobs. Given that full employment induced by a non-market mechanism would be detrimental for a meritocratic income distribution, we assume that meritocrats oppose the governmental policies that aim at assuring full employment. Generally, we agree with Sen (2000: 14) that 'the rewarding of merit and the very concept of merit itself depend on the way we see a good society and the criteria we invoke to assess the successes and failures of societies.'

In Table 1, we provide questionnaire items used in our scale of support for meritocratic distribution of income. The first item-pertaining to education and 
Table 1 Questionnaire items and pro-meritocratic responses for the summative scale

\section{Questionnaire item}

Total sample

SD

Average score

$\boldsymbol{\sigma}$

Residual variable

How important do you think that should be in deciding pay: the number of years spent in education and training?

First, the amount of responsibility that goes with the job-how important do you think that should be in deciding pay?

Pro-meritocratic response: essential

How important should that be in deciding pay: how well the person does the job?

Pro-meritocratic response:

essential

How important should that be in deciding pay: what is needed to support a family?

Pro-meritocratic response:

Not important at all and not very important How important should that be in deciding pay: whether the person has children to support?

Pro-meritocratic response:

Not important at all and not very important The government should provide jobs for everyone who wants one.

Pro-meritocratic response:

Strongly disagree and disagree
0.46

0.366

0.31

0.26

0.44

0.482

0.35

0.48

0.477

0.22

0.42

0.595

0.30

0.46

0.602

0.21

0.41

0.464
Item correlation with the scale $\Gamma$ 
construction, we argue that support for meritocracy is not a latent variable 'causing' particular responses to the questionnaire items. Rather it is a stance, which might be viewed as an aggregate of various opinions about the relationship between merit and rewards. There is no a priori reason why pro-meritocratic opinion in one respect should be linked to promeritocratic opinion in different respect. Since all of our items meet face value criterion of measuring pro-meritocratic stance, we use them regardless of how they are correlated with each other. Thus, we opt for summation scale rather than that based on factor analysis. ${ }^{3}$ The values of the final index range from 0 to 6 , with the mean 1.65 , and SD 1.32 .

In Table 1, we provide correlations of the index with each item. Overall, correlations are moderate (0.366 to 0.602 ) but meet conventional standards of index construction. In substantive terms, the index is loaded with items pertaining to anti-need-orientation. In particular, the index correlates highly $(r>0.5)$ with two items that evaluate whether supporting a family and whether having children should not be important in deciding future pay. Since meritocratism is antithetical to the need-orientation, we accept this feature of the index.

\section{Measurement of Individual Independent Variables}

The two main determinants of support for meritocracy, respondent's education and income, are measured in a conventional way. Education is expressed in terms of school-years. We standardized the income distribution for each country to avoid difficulties with transforming different currencies into a common metric. Thus, individual incomes should be interpreted as an inter-country positional measure.

We also include age and gender. Younger people are better educated and they should support meritocracy to the greater degree than older people. However, the reverse relationship might be expected if someone takes into account that having longer experience on the labour market 'teaches' employees that meritocracy is a more productive system than that based on needs. Because of these competing expectations, we treat age only as control variable. It is expressed in term of years.

According to our hypothesis, women should support a meritocratic distribution of income more than men. While women's income correlates with education on a similar level as in the case of men, the labour market moving toward meritocracy would bring greater gains to women in comparison to men. Rationally, it is in the interest of women to support meritocracy. To reflect the posited relation by positive slope, women are coded 1 and men 0 .

\section{Societal Degree of Meritocracy and Other Characteristics of Countries}

The meritocratic principle, as understood in this article, requires that more educated persons should not have lower incomes than less educated ones. Equivalently, persons at a given level of education should have an income equal to or higher than the income of persons at a lower level of education. Given a univariate distribution of education and a univariate distribution of income, the meritocratic principle, stated formally, determines the joint distribution of the two. This bivariate distribution, called meritocratic allocation, is obtained according to an algorithm (Krauze and Slomczynski, 1985) that is an operationalization of Thurow (1975) idea of queuing as a job allocation mechanism (for an application, see Wang 2002). The basic features of this allocation have been known since the work of Anderson (1961) (see also Boudon, 1974; Hope, 1984) and utilized in the context of simulation analysis of the relationship between education and social mobility. For a given population assigned to given levels of education and income, the meritocratic allocation can be found as a solution of a linear programming that optimizes the relationship between education and income. According to such solution, the correlation between these two variable reaches its maximum under the distributional constrains.

Table 2 provides an example of both observed and meritocratic allocation (panels A and B). Computing values of the index of dissimilarity between these allocations (panel C), we determine the percentage of persons who should be moved to achieve the ideal meritocracy. Since this percentage (D) can be interpreted as a distance from meritocracy, its difference from 100 is a measure to what extent a country is meritocratic, $M=100-D$. Thus, the higher the value of $\mathrm{M}$, the more meritocratic is the country.

In Table 3, we provide the values of $\mathrm{M}$ for all countries. According to this measure the most meritocratic countries are East Germany, the United States, Czechoslovakia, Australia, Bulgaria, and Norway. Russia, Poland and West Germany are the least meritocratic. The discrepancy between location of East Germany, Czechoslovakia, and Bulgaria on one hand, and Russia and Poland, on the other, shows different paths of the development of countries from the former Soviet block. In the 1950s and 1960s 
Table 2 Meritocratic allocation: an example

\begin{tabular}{lccccc}
$\begin{array}{l}\text { Education } \\
\text { categories (i) }\end{array}$ & \multicolumn{4}{c}{ Income categories (j) } \\
1 & 2 & 3 & 4 & 5 \\
(High) & & & & (Low)
\end{tabular}

\begin{tabular}{lrrrrrr}
\hline \multicolumn{7}{c}{ A. Observed Allocation (\%) } \\
1 (High) & 5.1 & 3.1 & 1.4 & 1.6 & 1.0 & 12.2 \\
2 & 4.7 & 4.5 & 3.7 & 3.4 & 2.7 & 18.9 \\
3 & 2.5 & 2.9 & 2.9 & 3.3 & 2.7 & 14.2 \\
4 & 5.6 & 6.9 & 7.6 & 7.2 & 9.0 & 36.3 \\
5 (Low) & 1.9 & 2.9 & 4.5 & 4.8 & 4.3 & 18.4 \\
& 19.8 & 20.2 & 20.1 & 20.2 & 19.7 &
\end{tabular}

B. Meritocratic allocation (\%)

$\begin{array}{lrrrrrr}1 \text { (High) } & 12.2 & & & & & 12.2 \\ 2 & 7.6 & 11.3 & & & & 18.9 \\ 3 & & 8.9 & 5.3 & & & 14.2 \\ 4 & & & 14.8 & 20.2 & 1.3 & 36.3 \\ 5 \text { (Low) } & & & & & 18.4 & 18.4 \\ & 19.8 & 20.2 & 20.1 & 20.2 & 19.7 & 100.0\end{array}$

C. Difference $(\mathbf{A}-\mathbf{B})$

$\begin{array}{lrrrrr}1 \text { (High) } & -7.1 & 3.1 & 1.4 & 1.6 & 1.0 \\ 2 & -2.9 & -6.8 & 3.7 & 3.4 & 2.7 \\ 3 & 2.5 & -6.0 & -2.4 & 3.3 & 2.7 \\ 4 & 5.6 & 6.9 & -7.2 & -13.0 & 7.7 \\ 5 \text { (Low) } & 1.9 & 2.9 & 4.5 & 4.8 & -14.1 \\ & \mathrm{D}=59.6 \% & \mathrm{M}=100-\mathrm{D}=40.4 \%\end{array}$

Table 3 Measurement of actual meritocracy

\begin{tabular}{lccr} 
Country & $\begin{array}{c}\text { Degree } \\
\text { of actual } \\
\text { meritocracy } \\
\mathbf{1 9 9 2}\end{array}$ & $\begin{array}{c}\text { Educational } \\
\text { stock }^{\mathbf{a}}\end{array}$ & $\begin{array}{c}\text { National } \\
\text { wealth }^{\mathbf{b}}\end{array}$ \\
\hline Australia & $\mathbf{1 9 8 7}$ & $\mathbf{1 9 8 7}$ \\
Bulgaria & 51.26 & 29 & 13.27 \\
Canada & 49.10 & 23 & 2.92 \\
Czechoslovakia & 57.17 & 58 & 16.76 \\
East Germany & 62.16 & 16 & 3.35 \\
Great Britain & 47.20 & 22 & 7.47 \\
Hungary & 47.87 & 15 & 12.79 \\
Italy & 48.45 & 24 & 13.50 \\
New Zealand & 48.98 & 36 & 10.19 \\
Norway & 51.84 & 35 & 19.13 \\
Poland & 44.00 & 18 & 3.20 \\
Russia & 35.10 & 23 & 5.12 \\
United States & 60.72 & 60 & 19.70 \\
West Germany & 44.42 & 32 & 14.37 \\
\hline
\end{tabular}

${ }^{a}$ Measured as the percent of the population in tertiary education (World Bank, 1997).

${ }^{b}$ Measured as GNP per capita (World Bank, 1997). all these countries were similar with respect to the association between education and income, since the same rules of allocating money on the labour market were uniformly controlled by the communist party. The method of assigning earnings to qualifications, called 'tarification', was strictly applied, with two notable exceptions: communist party positions and heavy industry. The labour market imbalances accompanying the erosion and dismay of the communist system differed country by country.

The discrepancy between the location of the United States and West Germany demonstrates the internal differentiation among traditional capitalist countries. To be sure that such patterns are not artificial products of the method we used, we compared our M-scale with that obtained according to the simplest measure of meritocracy, that is the bivariate correlation between education and earnings. Overall, the ranking of countries according to both these measures coincide to a great extent. However, our measure is preferable since it reflects the necessary mobility to achieve an ideal state of meritocracy.

Since in our theoretical model we include two determinants of the degree of societal meritocracyeducational stock and national wealth-in Table 3 we provide values of these variables for all 14 countries. Both these variables do not share more than 50 per cent of common variance; their correlation with meritocracy is modest $(0.2<r<0.3)$.

\section{Results}

\section{Within-Country Patterns}

Within each country, there is a tendency that the higher the level of education the stronger is the level of support for a meritocratic distribution of income. However, the strength of this tendency, expressed in terms of a correlation between an individual's years of education and their meritocratic beliefs, varies among countries: it is strongest in Poland, Czechoslovakia, and Hungary $(r>0.250)$ and lowest in East and West Germany, Italy, New Zealand, and Russia $(r<0.125)$. In all countries included in our analysis this correlation is statistically significant $(P<0.01)$.

With the exception of East Germany, the correlation of individual earnings and support for meritocracy is also positive and statistically significant. The strongest correlation occurs in Great Britain $(r=0.305)$ followed by New Zealand, Canada, and West Germany $(r>0.230)$. In the remaining cases, this correlation varies between 0.100 and 0.200 . Thus, there is a tendency whereby people with higher levels of earnings 
Table 4 Regression of support for meritocracy on age, sex, education, income for 14 countries, 1992

\begin{tabular}{|c|c|c|c|c|c|c|c|c|c|c|}
\hline \multirow[t]{2}{*}{ Country } & \multicolumn{2}{|c|}{ Age } & \multicolumn{2}{|c|}{ Sex } & \multicolumn{2}{|c|}{ Education } & \multicolumn{2}{|c|}{ Income } & \multirow[t]{2}{*}{ Constant } & \multirow{2}{*}{$\begin{array}{l}\text { Adjusted } \\
R \text {-squared }\end{array}$} \\
\hline & $b$ & $\beta$ & $b$ & $\beta$ & $b$ & $\beta$ & $b$ & $\beta$ & & \\
\hline Australia & $\begin{array}{c}0.000 \\
(0.004)\end{array}$ & 0.002 & $\begin{array}{c}0.120 \\
(0.104)\end{array}$ & 0.038 & $\begin{array}{c}0.075 \\
(0.017)\end{array}$ & $0.153^{*}$ & $\begin{array}{c}0.196 \\
(0.047)\end{array}$ & $0.144^{*}$ & $\begin{array}{l}1.023 \\
(0.301)\end{array}$ & 0.054 \\
\hline Great Britain & $\begin{array}{c}-0.004 \\
(0.004)\end{array}$ & -0.038 & $\begin{array}{c}-0.186 \\
(0.090)\end{array}$ & $-0.068^{*}$ & $\begin{array}{c}0.123 \\
(0.031)\end{array}$ & $0.145^{*}$ & $\begin{array}{c}0.312 \\
(0.046)\end{array}$ & $0.244^{*}$ & $\begin{array}{c}0.464 \\
(0.443)\end{array}$ & 0.118 \\
\hline Bulgaria & $\begin{array}{c}0.010 \\
(0.004)\end{array}$ & $0.072^{*}$ & $\begin{array}{c}0.162 \\
(0.082)\end{array}$ & $0.067^{*}$ & $\begin{array}{c}0.049 \\
(0.015)\end{array}$ & $0.111^{*}$ & $\begin{array}{c}0.166 \\
(0.041)\end{array}$ & $0.139^{*}$ & $\begin{array}{c}0.814 \\
(0.262)\end{array}$ & 0.042 \\
\hline Canada & $\begin{array}{r}-0.010 \\
(0.005)\end{array}$ & $0.022^{*}$ & $\begin{array}{c}0.132 \\
(0.094)\end{array}$ & 0.047 & $\begin{array}{c}0.060 \\
(0.022)\end{array}$ & $0.096^{*}$ & $\begin{array}{c}0.354 \\
(0.055)\end{array}$ & $0.254^{*}$ & $\begin{array}{l}1.343 \\
(0.374)\end{array}$ & 0.077 \\
\hline Czechoslovakia & $\begin{array}{c}0.002 \\
(0.004)\end{array}$ & 0.015 & $\begin{array}{c}-0.162 \\
(0.091)\end{array}$ & $-0.059^{* *}$ & $\begin{array}{c}0.145 \\
(0.016)\end{array}$ & $0.301^{*}$ & $\begin{array}{c}0.098 \\
(0.047)\end{array}$ & $0.072^{*}$ & $\begin{array}{c}-0.156 \\
(0.274)\end{array}$ & 0.116 \\
\hline East Germany & $\begin{array}{c}0.001 \\
(0.004)\end{array}$ & 0.012 & $\begin{array}{c}0.226 \\
(0.076)\end{array}$ & $0.099^{*}$ & $\begin{array}{c}0.036 \\
(0.013)\end{array}$ & $0.095^{*}$ & $\begin{array}{c}0.026 \\
(0.039)\end{array}$ & 0.023 & $\begin{array}{c}0.864 \\
(0.212)\end{array}$ & 0.019 \\
\hline Hungary & $\begin{array}{c}0.011 \\
(0.004)\end{array}$ & $0.087^{*}$ & $\begin{array}{c}0.064 \\
(0.084)\end{array}$ & 0.025 & $\begin{array}{c}0.107 \\
(0.016)\end{array}$ & $0.239^{*}$ & $\begin{array}{c}0.071 \\
(0.046)\end{array}$ & 0.057 & $\begin{array}{c}-0.198 \\
(0.273)\end{array}$ & 0.074 \\
\hline Italy & $\begin{array}{c}-0.015 \\
(0.004)\end{array}$ & $-0.141^{*}$ & $\begin{array}{r}-0.154 \\
(0.081)\end{array}$ & $-0.063^{* *}$ & $\begin{array}{c}0.011 \\
(0.010)\end{array}$ & 0.039 & $\begin{array}{c}0.129 \\
(0.038)\end{array}$ & $0.117^{*}$ & $\begin{array}{c}1.758 \\
(0.218)\end{array}$ & 0.043 \\
\hline New Zealand & $\begin{array}{c}-0.005 \\
(0.004)\end{array}$ & -0.039 & $\begin{array}{c}0.138 \\
(0.101)\end{array}$ & 0.045 & $\begin{array}{c}0.016 \\
(0.014)\end{array}$ & 0.038 & $\begin{array}{c}0.364 \\
(0.050)\end{array}$ & $0.256^{*}$ & $\begin{array}{c}2.054 \\
(0.268)\end{array}$ & 0.068 \\
\hline Norway & $\begin{array}{c}-0.013 \\
(0.004)\end{array}$ & $-0.118^{*}$ & $\begin{array}{c}0.212 \\
(0.089)\end{array}$ & $0.084^{*}$ & $\begin{array}{c}0.060 \\
(0.014)\end{array}$ & $0.155^{*}$ & $\begin{array}{c}0.226 \\
(0.047)\end{array}$ & $0.183^{*}$ & $\begin{array}{c}1.077 \\
(0.260)\end{array}$ & 0.087 \\
\hline Poland & $\begin{array}{c}0.023 \\
(0.004)\end{array}$ & $0.160^{*}$ & $\begin{array}{c}0.094 \\
(0.091)\end{array}$ & 0.033 & $\begin{array}{c}0.185 \\
(0.017)\end{array}$ & $0.346^{*}$ & $\begin{array}{c}0.175 \\
(0.044)\end{array}$ & $0.128^{*}$ & $\begin{array}{c}-1.129 \\
(0.284)\end{array}$ & 0.156 \\
\hline Russia & $\begin{array}{c}0.001 \\
(0.003)\end{array}$ & 0.007 & $\begin{array}{c}-0.167 \\
(0.061)\end{array}$ & $-0.091^{*}$ & $\begin{array}{c}0.033 \\
(0.010)\end{array}$ & $0.113^{*}$ & $\begin{array}{c}0.060 \\
(0.030)\end{array}$ & $0.067^{*}$ & $\begin{array}{c}0.736 \\
(0.187)\end{array}$ & 0.029 \\
\hline United States & $\begin{array}{c}0.005 \\
(0.005)\end{array}$ & 0.035 & $\begin{array}{c}0.385 \\
(0.100)\end{array}$ & $0.131^{*}$ & $\begin{array}{c}0.108 \\
(0.019)\end{array}$ & $0.193^{*}$ & $\begin{array}{c}0.177 \\
(0.054)\end{array}$ & $0.123^{*}$ & $\begin{array}{c}0.329 \\
(0.346)\end{array}$ & 0.074 \\
\hline West Germany & $\begin{array}{c}0.002 \\
(0.004)\end{array}$ & 0.021 & $\begin{array}{c}0.165 \\
(0.091)\end{array}$ & $0.062^{* *}$ & $\begin{array}{c}0.022 \\
(0.013)\end{array}$ & $0.059^{* *}$ & $\begin{array}{c}0.282 \\
(0.045)\end{array}$ & $0.234^{*}$ & $\begin{array}{c}0.970 \\
(0.234)\end{array}$ & 0.064 \\
\hline
\end{tabular}

${ }^{*} P>0.05,{ }^{* *} P>0.10$

Standard errors in parentheses.

support a meritocratic distribution of income more than people with lower levels of earnings.

With notable exceptions, these two tendencies are also clear in the regression framework (Table 4). In the equation explaining support for a meritocratic distribution of income slopes for education and earnings are positive and significant in 10 of the 14 countries. The notable exceptions are Italy and New Zealand in the case of education, and East Germany and Hungary in the case of earnings. In these countries the net pro-meritocratic impact of either education or earnings is essentially washed out since, as we already mentioned, the respective bivariate correlations were low. It is important to note that education was coded in a crude manner in both Italy and New Zealand and a large standard error for the regression coefficient might be a purely methodological effect. However, the weak impact of earnings in East Germany and Hungary is likely to be of a substantive nature. In these countries, the economic turmoil associated with the initial phase of the post-communist transition resulted in dramatic fluctuations in earnings making it difficult for earnings to exercise any observable impact on equity beliefs.

Generally, the effects of education and income are linear and additive. We did not detect any interaction effects of these variables on the level of countries. In other words, status inconsistency involving education and income does not affect pro-meritocratic attitudes above and beyond the impact of these two variables.

There is no significant effect for age in more than half of the countries. In those countries where the effect is significant, age has a negative effect in Norway 


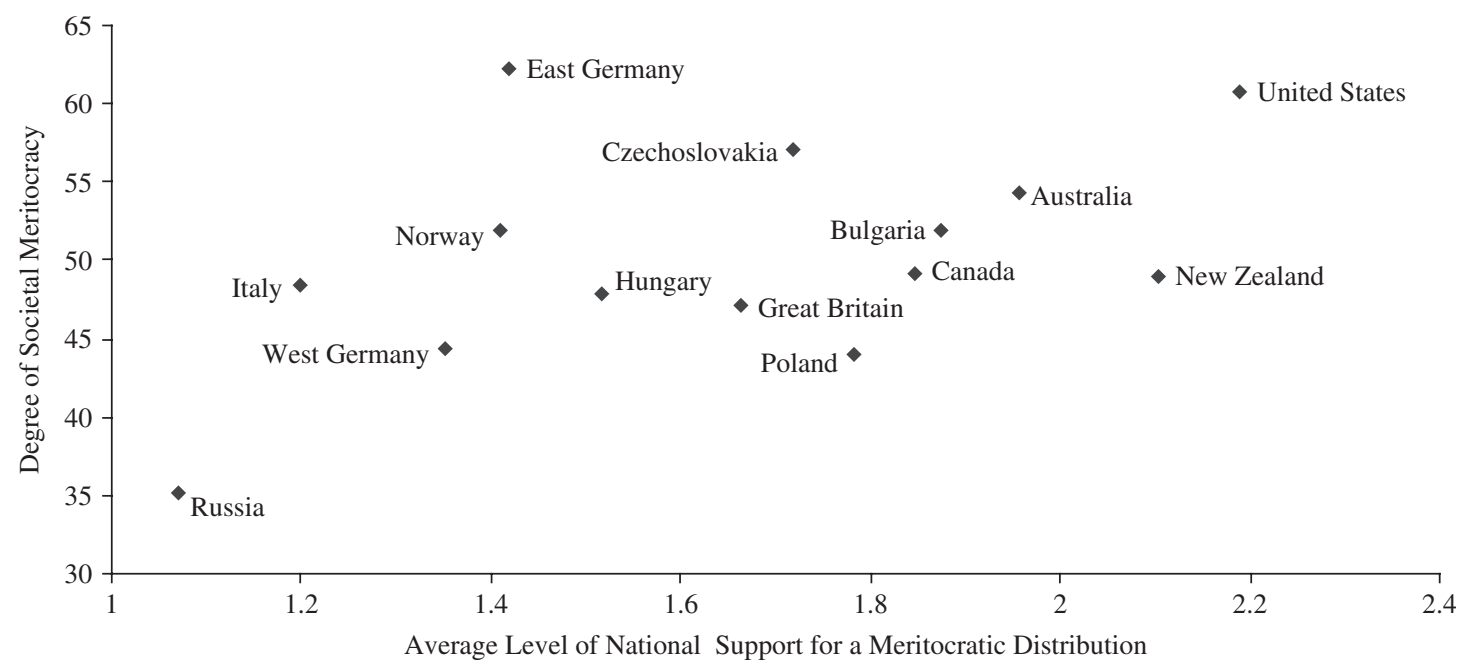

Figure 2 Relationship between degree of meritocracy and average value of support for meritocracy

and Italy, while it has a positive effect in Canada, Bulgaria, Hungary, and Poland. Given the fact that both Italy and Norway are classic welfare states while the other four countries in 1992 were adopting more pro-market policies these findings confirm the fact that age impacts attitudes in different ways, depending on other macro-conditions.

With respect to our expectation that women would be more pro-meritocratic than men, our findings are somewhat mixed. To begin with in nine of the 14 countries we find significant differences between women and men's levels of support for a meritocratic distribution of income. In four of these countries, Great Britain, Czechoslovakia, Italy, and Russia women are less supportive of a meritocratic distribution than men, while in the remaining five countries, Bulgaria, East Germany, Norway, the United States, and West Germany women are more supportive than men. The fact that women are more supportive of the market policies then men corresponds to our theoretical expectation and other findings (Zagórski, 1998).

All together, depending on a country, four variables-sex, age, education, and earnings-explain from 2 per cent to 16 per cent of variance of our index of the support for meritocracy. This is in agreement with typical studies of the impact of the basic demographic and stratification variables on attitudes.

\section{Across Country Patterns}

In Figure 2, we present the overall relationship between the degree of societal meritocracy (measured by our index M) and the average level of national support for a meritocratic distribution of income. Great Britain, Canada, Australia, New Zealand, and the United States are relatively meritocratic countries not only in terms of actual relationship between education and income but also in terms of the popular support for meritocracy. All of these countries are well-established capitalist democracies where national sentiment in the early 1990s went into the direction of pro-market and anti-welfare state solutions. At that time, other well-established capitalist democracies-Italy, Norway, and West Germany-were slightly less meritocratic in both objective and subjective dimensions. In these countries, elites and the public supported significant welfare state provisions to cope with internal economic difficulties. The core of East and EastCentral European countries-East Germany, Hungary, Poland, Czechoslovakia, and Bulgaria-lies between these two groups. Russia is an exception with the lowest degree of actual meritocracy and the lowest degree of popular support for a meritocratic distribution of income.

\section{Final Models}

Given the hierarchical structure of our data, individuals nested within countries, ordinarily least squares (OLS) regression would be inappropriate to determine the effects of individual and contextuallevel variables across countries. Hierarchical data structures have been shown to violate basic assumptions of OLS regression because of the presence of 
Table 5 Support for meritocracy: an HLM within country model

Variables

Gamma coefficient

Basic model ${ }^{\mathrm{a}}$

Standard

t-statistic

error

\begin{tabular}{lllr}
\hline Intercept & 0.0096 & 0.0623 & 0.154 \\
Age & 0.0057 & 0.0109 & 0.523 \\
Female & $0.0584^{*}$ & 0.0227 & 2.573 \\
Education & $0.1481^{*}$ & 0.0118 & 12.564 \\
Income & $0.1412^{*}$ & 0.0114 & 12.345 \\
$\begin{array}{l}\text { Within-country variance } \\
\quad \text { explained (\%) }\end{array}$ & 5.21 & & \\
$\begin{array}{l}\text { Between-country variance } \\
\quad \text { explained (\%) }\end{array}$ & 16.07 & & \\
\hline
\end{tabular}

\begin{tabular}{lcccc} 
Parameter & $\begin{array}{c}\text { Estimated } \\
\text { parameter } \\
\text { variance }\end{array}$ & $\begin{array}{c}\text { Chi-square table } \\
\text { Degrees of } \\
\text { freedom }\end{array}$ & Chi-square & $\boldsymbol{P}$-value \\
\hline $\begin{array}{l}\text { Intercept } \\
\text { Level-1 }\end{array}$ & 0.0528 & 13 & 573.61 & 0.000 \\
\hline
\end{tabular}

${ }^{*} \mathrm{P}<0.05$ (two-tailed)

${ }^{a}$ All level-1 predictors have been centered around their grand means. The residual parameter variance for all level-1 predictors has been set to zero.

case-dependency and heteroskedasticity. Therefore, we present results in Tables 5 and 6 using HLM to avoid some obvious shortcomings of OLS regression applied to contextual variables.

We first determine if support for a meritocratic distribution of income varies among countries. Using a one-way analysis of variance (ANOVA) model with random effects-also known as a fully conditional model-we are able to determine what proportion of the variance of support for meritocratic pay is attributable to between and within country components. In other words, what percent of variance in support for meritocratic pay can be attributed to country and individual-level variables?

Results suggest that 6 per cent of the variance in support for a meritocratic distribution of income is attributable to country-level differences. The betweencountry variances (Tau) in support for a meritocratic distribution of income is 0.063 . With a chi-square statistics of 610.8 and 13 degrees of freedom, the between-country variance in meritocratic attitudes is significant at the 0.001 level. Therefore, results from the fully unconditional model suggest that a significant amount of the variance in support for a meritocratic distribution of incomes exists between countries.
In Table 5, we estimate a random coefficient regression model in which only individual level predictors are included to determine if individual characteristics such as, education, income, sex, and age affect support for a meritocratic distribution of income. Results from the random coefficient regression model suggest that education and income are both significant positive predictors of support for a meritocratic distribution of income. A one-unit increase in education increases support for a meritocratic distribution of income by 0.148 . While age does not have a significant effect, women are significantly more likely to support a meritocratic distribution of income than men. The individual-level variables explain 5.21 per cent of the within-country variance and 16.07 per cent of the between- country variance in support for a meritocratic distribution of income. ${ }^{4}$ Therefore, a significant amount of the between-country variation in support for a meritocratic distribution of income remains to be explained.

In Table 6, we estimate two intercepts as outcomes models to determine if societal meritocracy, educational stock, national wealth, and previous experience under a communist regime explain differences in support for a meritocratic distribution of income. This type of hierarchical linear model examines 
Table 6 Support for meritocracy: an HLM intercept as outcome model ${ }^{\mathrm{a}}$

\begin{tabular}{|c|c|c|c|c|c|c|}
\hline \multirow[t]{2}{*}{ Variables } & \multirow{2}{*}{$\begin{array}{c}\text { Gamma } \\
\text { coefficient }\end{array}$} & \multicolumn{2}{|c|}{ Model 1} & \multirow{2}{*}{$\begin{array}{l}\text { Gamma } \\
\text { coefficient }\end{array}$} & \multicolumn{2}{|c|}{ Model 2} \\
\hline & & SE & t-statistic & & SE & t-statistic \\
\hline Intercept & $0.2920^{*}$ & 0.1067 & 2.736 & 0.2283 & 0.1285 & 1.777 \\
\hline $\begin{array}{l}\text { Country-level variables } \\
\text { Degree of meritocracy }\end{array}$ & $0.1271^{*}$ & 0.0504 & 2.521 & & & \\
\hline National wealth & $-0.4586^{*}$ & 0.1434 & -3.197 & $-0.3837^{*}$ & 0.1739 & -2.207 \\
\hline Educational stock & $0.1856^{*}$ & 0.0771 & 2.408 & $0.2147^{*}$ & 0.0944 & 2.274 \\
\hline $\begin{array}{l}\text { Post-communist country } \\
\text { Individual-level variables }\end{array}$ & $-0.6590^{*}$ & 0.2265 & -2.909 & -0.5105 & 0.2710 & $-1.884^{* *}$ \\
\hline Age & 0.0056 & 0.0109 & 0.516 & 0.0057 & 0.0109 & 0.523 \\
\hline Female & $0.0588^{*}$ & 0.0227 & 2.587 & $0.0586^{*}$ & 0.0227 & 2.578 \\
\hline Education & $0.1473^{*}$ & 0.0118 & 12.495 & $0.1474^{*}$ & 0.0118 & 12.496 \\
\hline Income & $0.1414^{*}$ & 0.0114 & 12.371 & $0.1414^{*}$ & 0.0114 & 12.362 \\
\hline
\end{tabular}

Chi-square table

\begin{tabular}{|c|c|c|c|c|c|c|c|c|}
\hline Parameter & $\begin{array}{c}\text { Estimated } \\
\text { parameter } \\
\text { variance }\end{array}$ & $\begin{array}{l}\text { Degrees of } \\
\text { freedom }\end{array}$ & Chi-square & $P$-value & $\begin{array}{c}\text { Estimated } \\
\text { parameter } \\
\text { variance }\end{array}$ & $\begin{array}{l}\text { Degrees of } \\
\text { freedom }\end{array}$ & Chi-square & $P$-value \\
\hline $\begin{array}{l}\text { tercept } \\
\text { evel-1 }\end{array}$ & $\begin{array}{l}0.0260 \\
0.8131\end{array}$ & 9 & 167.62 & 0.000 & $\begin{array}{l}0.04077 \\
0.8131\end{array}$ & 10 & 358.35 & 0.000 \\
\hline
\end{tabular}

${ }^{*} P<0.05$ (two-tailed).

${ }^{* *} P<0.10$ (two-tailed).

${ }^{a}$ All level-1 predictors have been centered around their grand means. The residual parameter variance for all level-1 predictors has been set to zero. All level-2 predictors have been centered around their grand means.

cross-level interactions between the country-level predictors and the support for a meritocratic distribution of income intercept. Results from the intercepts as outcomes models provide support for most of our hypotheses.

As predicted an increase in the degree of societal meritocracy increases support for a meritocratic distribution of income (see Table 6, Model 1). A one-unit positive change in the degree of societal meritocracy increases support for a meritocratic distribution of income by 0.1271 . In addition, the educational stock of a nation, measured as the percent of persons in tertiary education, also increases support for a meritocratic distribution of income. Unexpectedly, increases in national wealth, measured as GNP/capita, actually decrease support for a meritocratic distribution of income. Finally, prior experience under a communist regime decreases support for a meritocratic distribution of income as expected. The individual and country-level variables in Model 1 account for 60 per cent of the between-country variance.
In Model 2, we present a second set of results to determine what proportion of the between-country variance can be attributed to the degree of societal meritocracy. Results show that 23.5 per cent of the between-country explained variance can be attributed to the degree of societal meritocracy. These results provide support for our major hypothesis linking systems of distribution with a sense of equity. In particular, the degree of societal meritocracy does in fact significantly affect support for a meritocratic rule, net of an individual's position in the social structure and additional characteristics about the societies they are living in.

\section{Discussion and Conclusion}

Previous research on the determinants of attitudes towards social inequality, in particular meritocratic attitudes, has not included both individual and country-level determinants, and their interaction. Researchers have focused primarily on differences in within-country patterns of support for a merit-based 
distribution, speculating only on cross-national differences. In contrast, our study is the first to examine under what societal level conditions an individual will legitimate inequalities in future pay on the basis of merit. Analyses presented in this article establish several important findings.

First, previous researchers have used a latent construct to measure meritocratic attitudes in singlenation or comparative studies of fewer than four countries (Mateju and Rehakova, 1992; Mateju and Tucek, 1992; Shepelak, 1989). As a result, they were not particularly concerned with establishing withinand between-country equivalence of their dependent variable. Identifying a valid measure of support for meritocracy that is reliable across countries is a critical component of a comparative analysis. We concluded that a latent construct is not a valid measure for a larger set of countries. Rather, a summed index is more appropriate. In choosing this strategy of index construction, we argue that support for meritocracy is not a latent variable 'causing' particular responses to the questionnaire items. It is a stance, which might be viewed as an aggregate of various opinions about the relationship between merit and rewards. We recommend this scale for future research on attitudes toward meritocracy.

Second, in this analysis, we explain a relatively large proportion of the between-country variation in support for a meritocratic distribution of income. We show that significant differences in mean levels of support for a meritocratic distribution of income are the result of societal characteristics, in particular the degree to which a meritocratic assignment of individuals has occurred. The concept of meritocracy refers to both a social system, where the relationship between merit and desired rewards is particularly strong and also to a subjective evaluation of a legitimate basis of inequality. This analysis clearly shows that after controlling for an individual's position in the social structure, the degree to which their country has achieved a meritocratic distribution positively affects their support for a merit-based distribution.

Third, it is well known that acceptable levels of economic inequality vary from country to country (Kelley and Evans, 1993). In addition, single nation studies and comparative studies have determined that what is considered a legitimate basis for inequality varies as well (Kluegel et al., 1995; Locklear, 1998). Based on within-country regressions, we have shown that the relative importance of individual level characteristics varies. For instance, in Poland education is the most important determinant of support for meritocracy, while income is the most important determinant in New Zealand (Table 4). Although specific inter-country differences need to be accounted for in future research, generally our analyses support all hypotheses pertaining to the effects of individual level variables on a sense of equity. What previous research has not established though is the independent effect that both individual and country-level factors have on support for meritocracy. Our study is the first to show that the degree to which a country has adopted a meritocratic distribution of income positively affects support for such a system, controlling for an individual's position in the social structure.

The study of distributive justice attitudes continues to be important in both well-established democracies and newly emerging democracies. In well-established democracies individual attitudes towards systems of distribution influence the degree to which the state will be involved in the redistribution of resources (Esping-Anderson, 1990). In addition, scholars studying the transition to democracy in Eastern Europe, consistently warned that if the emerging economic inequalities were not viewed as legitimate it would threaten the pace of economic and political reforms (Przeworski, 1991). We extend this argument claiming that a sense of equity is an important variable in a general support for radical social change. Ideological legacy proved to be an obstacle in forming promeritocratic attitudes since at the early stage of transformation post-communist societies were less meritocratic than other industrialized countries, even if the level of actual meritocracy was controlled. It is interesting that in all these post-communist countries in which elites stressed pro-meritocratic basis for distribution of income-Poland, Hungary, the Czech Republic, and Slovakia-some observable advances in economic development were achieved. These advances were accompanied by the increase in pro-meritocratic attitudes as indicated by other studies. In particular, referring to the late 1990s, Redmond et al. (2002: 21) found 'no substantial east-west differences in the level of support for "objective" criteria in terms of earning determinants. People in both east and west appear to share basically the same views as to how earnings should be determined'. Thus, we were able to detect a cross-national difference that used to be important at the initial phase of the post-communist transformation, separating the path of development of Poland, Hungary, the Czech Republic, and Slovakia from that of Russia. Actual meritocracy and promeritocratic attitudes became important factors for 
understanding divergent paths of development of post-communist societies.

\section{Notes}

1. Following suggestions of our critics, we differentiate between capitalist societies, and distinguish between liberal, conservative, and social democratic welfare states. However, because of data limitation (small $\mathrm{N}$ representing each type of welfare state), we decided not to peruse this line of inquiry about inter-country differences hypothesized and documented in recent years (Gelissen, 2000; Andreß and Heien, 2001; Arts and Gelissen, 2001). For meritocratic attitudes, the distinction between post-communist states and traditional capitalist states is much more important than any division within capitalist welfare states.

2. We restrict our sample to full-time employees since in this case job income is relatively inter-person comparable in terms of its utility. This is not the case of part time employment due to great variation in employers' contributions to health and pension plans as well as other contract arrangements and work conditions. Thus, our estimates of the model parameters are meant for a specific reference population and should not be overgeneralized. In particular, the sex-specific selection to full-time employment, disallow our estimates for gender to be treated as valid for all working men and women.

3. In confirmatory factor analysis, lambda coefficients vary only from 0.4 to 0.6 . In consequence, the weights for all items lead to the comparable solution to that presented in this article; the correlation between the confirmatory factor solution and our index is above 0.9. However, we decided to rely on summation scale, with all weights equal 1, on substantive grounds: Each item contributes to the concept of meritocracy on its own rights, not because of its relations with other items, like in factor analysis.

4. Since we standardized income within countries, income does not contribute to the betweencountry variance.

\section{Acknowledgements}

We thank Robert Michael Kunovich and the anonymous reviewers at European Sociological Review for their helpful comments.

\section{References}

Alves, W. M. and Rossi, P.H. (1978). Who Should Get What? Fairness Judgments of the Distribution of Earnings. American Journal of Sociology, 84 (3), 541-564.

Anderson, A. C. (1961). A Skeptical Note on the Relation of Vertical Mobility to Education. American Journal of Sociology, 66 (3), 560-570.

Andreß, H. and Heien, T. (2001). Four Worlds of Welfare State Attitudes? A Comparison of Germany, Norway, and the United States. European Sociological Review, 17 (4), 337-356.

Arts, W. and Gelissen, J. (2001). Welfare States, Solidarity and Justice Principles: Does the Type Really Matter? Acta Sociologica, 44, 283-299.

Bell, D. (1973). The Coming of Post-Industrial Society: A Venture in Social Forecasting. New York: Basic Books.

Bell, D. (1996). The Cultural Contradictions of Capitalism (Paperback). New York: Harper Collins.

Bénabou, R. (2000). Meritocracy, Redistribution, and the Size of the Pie. In Arrow, K., Bowles, S. and Durlauf, S. (Eds), Meritocracy and Economic Inequality. Princeton, NJ: Princeton Univerity Press, pp. 317-339.

Bierhoff, H., Buck, W. E. and Klein, R. (1986). Social Context and Perceived Justice. In Bierhoff, H. W., Cohen, R. L. and Greenberg, J. (Eds), Justice in Social Relations. New York/London: Plenum Press, pp. $165-185$.

Boudon, R. (1974). Education, Opportunity, and Social Inequality. Wiley.

Cook, K. S. (1975). Expectations, Evaluations and Equity. American Sociological Review, 40 (3), 372-388.

Dahrendorf, R. (1968). Essays in the Theory of Society. Stanford: Stanford University Press.

Deutsch, M. (1975). Equity, Equality, and Need: What Determines Which Value will be Used as the Basis of Distributive Justice? Journal of Social Issues, 31 (3), 137-149.

Esping-Anderson, G. (1990). The Three Worlds of Welfare Capitalism. Princeton, New Jersey: Princeton University Press.

Gelissen, J. (2000). Popular Support for Institutionalized Solidarity: A Comparison Between European Welfare States. International Social Welfare, 9, 285-300.

Goldthorpe, J. H. (1996). Problems of 'Meritocracy'. In Erikson, R. and Jonsson, J. O. (Eds), Can 
Education be Equalized? Boulder, CO: Westview Press, pp. 255-287.

Halsey, A. H. (1967). The Sociology of Education. In Smelser, N. J. (Ed.), Sociology: An Introduction. New York: John Wiley \& sons, pp. 381-434.

Homans, G. C. (1967). Fundamental Social Processes. In Smelser, N. J. (Ed.), Sociology: An Introduction. New York: John Wiley \& Sons, pp. 27-78.

Hope, K. (1984). As Others See Us: Schooling and Social Mobility in Scotland and the United States. Cambridge, England: Cambridge University Press.

Husen, T. (1974). Talent, Equality, and Meritocracy. New York: Martinus Nijhoff.

Jasso, G. (1980). A New Theory of Distributive Justice. American Sociological Review, 45 (1), 3-32.

Jasso, G. (1978). On the Justice of Earnings: A New Specification of the Justice Evaluation Function. American Journal of Sociology, 83 (6), 1398-1419.

Jasso, G. and Rossi, P. H. (1977). Distributive Justice and Earned Income. American Sociological Review, 42 (4), 639-651.

Jonsson, J. O. (1989). Towards the Merit Selective Society? Unpublished Paper.

Kelley, J. and Evans, M. D. R. (1993). The Legitimation of Inequality: Occupational Earnings in Nine Nations. American Journal of Sociology, 99 (1), 75-125.

Kluegel, J. R., Mason D. S. and Wegener, B. (Eds) (1995). Social Justice and Political Change: Public Opinion in Capitalist and Post-Communist States. New York: Aldine de Gruyter.

Kluegel, J. R. and Miyano, M. (1995). Justice Beliefs and Support for the Welfare State in Advanced Capitalism. In Kluegel, J. R., Mason, D. S. and Wegener, B. (Eds), Social Justice and Political Change: Public Opinion in Capitalist and PostCommunist States. New York: Aldine de Gruyter, pp. 81-108.

Krauze, T. and Slomczynski, K. M. (1985). How Far to Meritocracy? Empirical Tests of a Controversial Thesis. Social Forces, 63 (3), 623-642.

Locklear, S. (1998). Meritocratic Image of Success and its Determinants: A Comparison of Poland and Hungary, 1987-88 and 1992. International Journal of Sociology, 28 (2), 65-90.

Mateju, P. and Rehakova, B. (1992). From Unjust Equality to Just Inequality and Social Justice in Contemporary Czechoslovakia. SociologickyCasopis, 28, 293-318.

Mateju, P. and Tucek, M. (1992). Declared Occupational Mobility and Change in the Role of Achievement Principles in Four Nations of East-Central Europe. Sociologicky-Casopis, 28, 123-128.

Przeworski, A. (1991). Democracy and the Market. New York: Cambridge University Press.

Redmond, G., Schnepf, S. V. and Suhrcke, M. (2002). Attitudes to Inequality after Ten Years of Transition. Innocenti Working Paper No. 88. Florence: UNICEF Innocenti Research Center.

Ritzman, R. L. and Tomaskovic-Devey, D. (1992). Life Chances and Support for Equality and Equity as Normative and Counternormative Distribution Rules. Social Forces, 70 (3), 745-763.

Robinson, R. and Bell, W. (1978). Equality, Success, and Social Justice in England and the United States. American Sociological Review, 43 (2), 125-143.

Saunders, P. (1995). Might Britain be a Meritocracy? Sociology, 29, 23-41.

Sen, A. (2000). Merit and Justice. In Arrow, K., Bowles, S. and Durlauf, S. (Eds), Meritocracy and Economic Inequality. Princeton, NJ: Princeton University Press, pp. 5-16.

Shepelak, N. J. (1989). Ideological Stratification: American Beliefs About Economic Justice. Social Justice Research, 3, 219-233.

Shepelak, N. J. and Alwin, D. F. (1986). Beliefs About Inequality and Perceptions of Distributive Justice. American Sociological Review, 51 (1), 30-46.

Slomczynski, K. M. and Wesolowski, W. (2001). Distributive Justice and Status (In)Consistency: A Theoretical Debate and Empirical Evidence. Polish Sociological Review, 3 (135), 299-312.

So, A. Y. (1990). Social Change and Development: Modernization, Dependency, and World-System Theories. Newbury Park: Sage Publications.

Svallfors, S. (2003). Welfare Regimes and Welfare Opinions: A Comparison of Eight Western Countries. Social Indicators Research, 64 (3), 495-520.

Swift, A. and Marshall, G. (1997). Meritocratic Equality of Opportunity: Economic Efficiency, Social Justice or Both? Journal of Policy Studies, 18, 35-48.

Thurow, L. C. (1975). Generating Inequality: Mechanisms of Distribution in the U.S. Economy. Basic Books.

Wang, C. (2002). Meritocratic Allocation of Persons to Jobs. In Slomczynski, K. M. (Ed.), Social Structure: Changes and Linkages. Warsaw: IFiS Publishers, pp. 57-78. 
Wesolowski, W. (1981). Stratification and Meritocratic Justice. Research in Social Stratification and Mobility, 1, 249-265.

World Bank. (1997). World Development Indicators [CD-ROM]. Washington DC: World Bank [Producer and Distributor].

Zagórski, K. (1998). Transformation, Reform and Attitudes to Neo-Corporatism in Poland, Finland and Australia. In Wnuk-Lipiński, E. (Ed.), Values and Radical Social Change: Comparing Polish and South-African Experience. Warsaw: ISP Publishers, Polish Academy of Sciences, pp. 111-140.

\section{Authors' Addresses}

Sheri Kunovich, Southern Methodist University, Department of Sociology, Campus Box 750192, Dallas, TX 75275, USA. Email: kunovich@smu.edu Kazimierz M. Slomczynski (to whom correspondence should be addressed), Ohio State University, Department of Sociology, 300 Bricker Hall, 190 North Oval Mall, Columbus, OH 43210, USA, Email: slomczynski.1@sociology.osu.edu

Manuscript received: January 2005

Appendix General description of data from International Social Survey Program: Social Inequality Module, 1992

Country $^{a}$

\begin{tabular}{|c|c|c|c|c|c|c|c|}
\hline & & Sample & & Questionnaire & & a qual & \\
\hline & $\begin{array}{l}\text { Original } \\
\text { sample } \\
\text { size }^{b}\end{array}$ & $\begin{array}{l}\text { Selected } \\
\text { cases }\end{array}$ & $\begin{array}{l}\text { Response } \\
\text { rate }\end{array}$ & & $\begin{array}{l}\text { Responses } \\
\text { pertaining to } \\
\text { attitudinal } \\
\text { questions }^{c}\end{array}$ & $\begin{array}{r}\mathrm{h} \\
\text { pe } \\
\text { socio } \\
\mathrm{q}\end{array}$ & $\begin{array}{l}\text { to } \\
\text { to } \\
\text { d }\end{array}$ \\
\hline Australia & 2203 & 906 & $72 \%$ & Self-completed & 2 & 3 & 2 \\
\hline Bulgaria & 1198 & 403 & $80 \%$ & Interviewed & 3 & 1 & 3 \\
\hline Canada & 1043 & 410 & $74 \%$ & Self-completed & 1 & 3 & 3 \\
\hline Czechoslovakia & 1101 & 569 & $78 \%$ & Not available & 1 & 3 & 2 \\
\hline East Germany & 1094 & 407 & $50 \%$ & Self-completed & 2 & 3 & 1 \\
\hline Great Britain & 1034 & 357 & $56 \%$ & Self-completed & 3 & 2 & 3 \\
\hline Hungary & 1235 & 521 & $83 \%$ & Interviewed & 2 & 1 & 3 \\
\hline Italy & 1000 & 350 & (NA) & Interviewed & 1 & 2 & 1 \\
\hline New Zealand & 1239 & 513 & $68 \%$ & Self-completed & 1 & 2 & 2 \\
\hline Norway & 1538 & 686 & $64 \%$ & Self-completed & 2 & 2 & 2 \\
\hline Poland & 1636 & 668 & $85 \%$ & Self-completed & 3 & 1 & 1 \\
\hline Russia & 1944 & 922 & $92 \%$ & Self-completed & 3 & 1 & 3 \\
\hline United States & 1273 & 546 & $84 \%$ & Self-completed & 1 & 1 & 1 \\
\hline West Germany & 2297 & 714 & $50 \%$ & Self-completed & 3 & 3 & 1 \\
\hline
\end{tabular}

1992 ISSP data
Questionnaire
administration

\begin{tabular}{|c|c|c|c|c|c|c|c|}
\hline \multirow[b]{2}{*}{ Australia } & \multirow{2}{*}{$\begin{array}{c}\begin{array}{c}\text { Original } \\
\text { sample } \\
\text { size }^{\mathbf{b}}\end{array} \\
2203\end{array}$} & \multirow{2}{*}{$\begin{array}{c}\text { Selected } \\
\text { cases } \\
\\
906\end{array}$} & \multirow{2}{*}{$\begin{array}{c}\begin{array}{c}\text { Response } \\
\text { rate }\end{array} \\
72 \%\end{array}$} & \multirow{2}{*}{ Self-completed } & \multirow{2}{*}{$\begin{array}{c}\begin{array}{c}\text { Responses } \\
\text { pertaining to } \\
\text { attitudinal } \\
\text { questions }\end{array} \\
2\end{array}$} & \multicolumn{2}{|c|}{$\begin{array}{c}\text { Responses } \\
\text { pertaining to } \\
\text { socio-demographic } \\
\text { questions }^{\mathrm{d}}\end{array}$} \\
\hline & & & & & & 3 & 2 \\
\hline Bulgaria & 1198 & 403 & $80 \%$ & Interviewed & 3 & 1 & 3 \\
\hline Canada & 1043 & 410 & $74 \%$ & Self-completed & 1 & 3 & 3 \\
\hline Czechoslovakia & 1101 & 569 & $78 \%$ & Not available & 1 & 3 & 2 \\
\hline East Germany & 1094 & 407 & $50 \%$ & Self-completed & 2 & 3 & 1 \\
\hline Great Britain & 1034 & 357 & $56 \%$ & Self-completed & 3 & 2 & 3 \\
\hline Hungary & 1235 & 521 & $83 \%$ & Interviewed & 2 & 1 & 3 \\
\hline Italy & 1000 & 350 & (NA) & Interviewed & 1 & 2 & 1 \\
\hline New Zealand & 1239 & 513 & $68 \%$ & Self-completed & 1 & 2 & 2 \\
\hline Norway & 1538 & 686 & $64 \%$ & Self-completed & 2 & 2 & 2 \\
\hline Poland & 1636 & 668 & $85 \%$ & Self-completed & 3 & 1 & 1 \\
\hline Russia & 1944 & 922 & $92 \%$ & Self-completed & 3 & 1 & 3 \\
\hline United States & 1273 & 546 & $84 \%$ & Self-completed & 1 & 1 & 1 \\
\hline West Germany & 2297 & 714 & $50 \%$ & Self-completed & 3 & 3 & 1 \\
\hline
\end{tabular}

Data quality

Note: Distribution statistics of all variables discussed in this article, as well as all additional analyses, are available from the authors.

${ }^{a}$ Austria, Slovinia, and Sweden are omitted since the national questionnaires in in these countries did not include some relevant items. Since our analysis is restricted to the industrialized world, we also omitted the Philippines.

${ }^{b}$ We apply two weighting procedures. The first procedure is included in the ISSP Social Inequality Module to correct for major country-specific sample bias. The second procedure, eliminating the effect of different sizes of national samples, employs weights that equalize the sample size so countries with small samples are scaled up. After employing both weighting procedures the overall size of the sample is 12,739.

${ }^{c}$ This value is constructed on the basis of 10 randomly selected items, which were asked in all 14 countries. Countries with a 1 have the lowest average number of missing cases on the 10 items while countries with a 3 had the highest average number of missing cases.

${ }^{d}$ The values in Column 1 are constructed on the basis of four basic individual characteristics: age, sex, education, and income. Countries with a 1 have the lowest average number of missing cases on the 4 items while countries with a 3 have the highest average. The values in Column 2 are constructed on the basis of 2 sets of items. First, marital status and employment status of one's spouse and number of hours worked and employment status. Countries with a 1 have the lowest average number of inconsistent answers, while countries with a 3 have the highest average number of inconsistent answers. For all countries the percent of cases with inconsistent answers is quite small. 